\title{
Future-Anxious Commitment and Its Influence on Potential Human Capitals and Social Problems Anticipation With Personal Fides Awareness as Mediating Variabel
}

\author{
(A Study for Outsourcing Lecturers and Teachersin South Sumatera-Indonesia)
}

\section{Eka Muzalfitri Ridwan}

Faculty of Economics, Sjakhyakirti University, Palembang, Indonesia email; kualasyiah@gmail.com

\begin{abstract}
South Sumatera is one of biggest city in Indonesia that has been developing in many kinds of infrastructures, not only in physical aspect but also in human resource aspect. One of trendsetter problems in that city arework status that are accustomed to having at professions like lecturers and teachers in South Sumatera generally and Palembang city specially. Many lecturers and teachers not only in state universities and state schools (like: elementary school, junior high school, and senior high school) but also in private universities and private schools have been having uncertain status that we can also say outsourcing lecturers and teachers since Indonesia Government decided a moratorium planning in recruiting candidates of public servants in Indonesia. It means, it will be big problems for lecturers and teachers in Indonesia (especially in South Sumatera), they will influence on public services (like: college students and students) even decrease potential human capital and other social problems because of lecturers' and teachers' uncertain status. Meanwhile in other countries (USA, England, Japan, New Zealand, Singapore, Germany, Korea, Philippine), outsourcing workers are a custom in those but it can not be implemented in South Sumatera because outsourcing workers in this city are not ready yet in their competencies, soft and hard skills, experiences, creative thoughts, internal motivations, independencies, and loyalty to the job. Besides that, there is custom in South Sumatera (Indonesia generally) that being an employee is a pride for themselves and their families even though the salaries are too low. This research had found two postulates to become novelties support motivation and commitment theoriesThe result of this research are there are strong influence of personal FIDES awareness on future-anxious commitment grades 0,98 (98\%), strong influence of personal FIDES awareness on potential human capital grades 0,79 (79\%), and strong influence of personal FIDES awareness on social problems anticipation grades 0,53 (53\%). Personal FIDES awareness (PAFIDES) rises because of uncertain job status and job scarcity, and PAFIDES can not strongly and directly influence on social problems anticipation (SOCPRA) but it will be strongly if it indirectly influences on SOCPRA by using mediating variable called future-anxious commitment.
\end{abstract}

Keywords: FIDES; future-anxious commitment; potential human capital; uncertain job status 


\section{Introduction}

South Sumatera is as one of a biggest city in Indonesia has some social problems. One of the problem is in human resource. This is can be specifically insist into psychologically human mindset. People in South Sumatera has a custom that being an employee is a pride not just only for him or herself but also for their families. This condition is very different if we compare with European, American, Japanese, Korean, and even Malaysian that they will be proud of being an outsourcing employee (Hofstede, 1980). This right now is very serious trouble because from the fact people in South Sumatera do not want to be entrepreneurs and in other way the government had been deciding a moratorium recruitment of the candidates of public servant in any sectors including profession of lecturers and teachers. It means, if all the outsourcing lecturers and teacher have uncertain status in their job and it will impact on their prosperity especially the honorarium (not salary). If this condition can not be removed, it will influence on other social problems like bad quality service to publics (college students and students), low productivity, low commitment and loyalty, high poverty, and unemployment increasing (Joan Marques, 2014).

Further research is needed to find and give micro andmacro solution (not only for the organization/company but also for the country problems like social and demographic problems). From this research, researcher has found that internal motivation by using his/her awareness and personal loyalty needed very much to survive someone's career and organization/company's lack of employees. An employee in nowadays globalization needs a specific talent, competency, bright task-orientation, less lackadaisicalness, hard working by high discipline, oriented-visionary, innovative-dynamic planner, having definite purpose and target, and flexible-communicative approach as a human being. Those can be measured by intrinsic motivation that been had by a futuristic employee or human resource (Ray, J. J., 1980). By exploring one's motivation is going to generate one's commitment and satisfaction to his/her job (Gary Jon Springer, 2015). Personal commitment can influence on one's work effectiveness and human capital increasing (Durkin, M., \& Bennett, H, 1999) but personal status in its job is a must in the organization until he/she can be self-confident enough to do his/her job in anytime (Department of Labor Women's Bureau, 2005).

There are some research gaps that can support this research until the outcomes of this research will be scientific as far as researchers wish. They are some published journals that support the relationship among motivation, job commitment, and human capital but the othersnot support it because the results of the research weren't proven enough. According to Nwachukwu Prince Ololube (2016) there is no relationship between teacher's motivation and its performance job and its own skill but its skill depends on its experience as long as he/she is a teacher. That statement is supported by Connell, J. P. \& Ryan, R. M (1984) that their result study yields teachers skill and intelligence in communicating with their student do not depend on teacher's motivation and commitment but their sympathy and hobbies to gathering with the children. The other side, Filak, V. F. \& Sheldon, K. M (2003) have the same result in their research that lecturer's motivation and commitment do not give impact on their performance and competencies and skill. Meanwhile, according to Roxanne Helm-Stevens and Orlando Griego (2009), their result yields that intrinsic and extrinsic motivation and job commitmentof lecturer and teacher influence significantly on their effectiveness and personal skill in service learning. That statement is also supported by John P. Meyer, David J. Stanley, 
Lynne Herscovitch, and Laryssa Topolnytsky (2002) that from their research yields there is strong relationship between personal motivation and perceived skill on their job mediated by affective, continuance and normative commitment.

From those pros and contras, researcher can contemplate that it is very interesting to find solution out from the research gap by exploring and discovering a new postulate until a theoretical novelty emerged from empirical and scientific studies.

\section{Review of Relevant Literature}

Improving a scientific research needs some studies of relevant literature to support the research until it can be implemented, beneficial, and proven to be used in public interests. In this research, researcher is trying to explore some relevant literatures to support the postulate that created.

\subsection{Motivation}

Motivation refers to the individual forces that account for the direction, level, and persistence of person effort expended at work (Scermerhorn, Hunt, and Osborn, 2010). According to Luthan (1998) motivation is the the process that arouses, energizes, directs, and sustains behavior and performance. It means if there is a motivation at one's self so there will be an internal push that can direct one's behavior until doing its performance or job effectiveness. That condition is similar with Lotham and Locke (1979) that he level of motivation and performance is higher when the individual has specific objectives established and when these objectives, even with a high level of difficulty, are accepted and are offered a performance feedback.

Horwitz et al (2003) predicted that employees get high motivation through challenging work environment and support of the top management. The condition must be created in the organization until .all the employees happy enough with the climate of the organization by giving them challenging jobs fairly to all employees and desiring to communicate between supervisor and employees.

\subsection{Commitment}

According to Morrow \& Wirth (1989) commitment related to occupation, profession, and career have been used somewhat interchangeably in the commitment literature. Researcher choose to use the term occupation rather than profession because we believe that both professionals and nonprofessionals can experience commitment to the work they doand participants in this research are lecturers and teachers who give a lecturer or a subject to their students. Meyer and Allen (1991) identified three distinct themes in thedefinition of commitment: commitment as an affective attachment to the organization, commitment as a perceived cost associated with leaving the organization, and commitment as anobligation to remain in the organization. They referred to thesethree forms of commitment as affective, continuance, and normative commitment.

Affective commitment (Meyer and Allen's, 1991) is strong desire to do the job completely with the authority and responsibility to get strong relationship among one and each others lay aside salaries, job position, and even career. 
Continuance commitment (Meyer and Allen's, 1991) is strong desire to do the job because of getting position and continent career in the organization and scaring of loosing the opportunities of organization.

Normative commitment (Meyer and Allen's, 1991) is one's desire to do the job and responsibility because it is their duty, responsibility and authority based on their position and because of that they deceive to get salaries and other facilities.

\subsection{HumanCapital}

In globalization era, human capital is number one the most important thing beside capital, material, machine and other supporting item in the organization. David G. Coolings and Geoffrey Wood (2015) give statement that human capital is strategic planning focused on the investment in the human asset or employee development and the involvement of employees in both their immediate job and the wider context in which it is embedded, reflecting the need for the organization to pro-actively respond to an increasingly dynamic environment until the employees can give a competitive advantage to the firm.

Birdi et al. (2008), defines human capital as perspective: empowerment, teamwork and extensive training. In the case of empowerment it was defined as 'passing considerable responsibility for operational management to individuals or teams (rather than keeping all decision-making at the managerial level). So, to develop human capital in the organization needed Skills formation and entrepreneurial development to compete in global competition.

\subsection{Job Status}

Ferong Yuan and Richard W. Woodman , 2010 in their research yields that job status is one' pride that he/she can get institutional trust to do authority and responsibility, and get expected image in the organization. From one's status in the organization can influence its self-confidence, job motivations, job commitment, job satisfaction, and even job performance. On the other research, job status can be defined as a permanent recognition of organization that to vanish employees' doubt with his/her position in the organization even though the work condition changed and it will impact on its self efficacy (Belinda Renee Barnett \& Lisa Bradley, 2010).

From this research, researcher can conclude that the role of one's status in the organization is so important because can make everyone self confident with its position and job, convinced of its authority and responsibility, convinced of its rate of salary/wage, convinced of its chain of command, and even proud of being employee in the organization, and can be predicted to the employees' job satisfaction, job performance, job motivation intrinsically and extrinsically, and impact on creating next new human capital.

\subsection{Novelties and Postulates}

From the relevant literatures, researcher can generate novelty in this research by substituting and adding new name of motivation and commitment theory. Job Motivation can be substituted by Personal FIDES Awarenessand Personal Commitment substituted by Future-Anxious Commitment.The postulate of Personal FIDES Awareness is an internalpersonal push for all mankind to make it conscious and come up because of its successful destiny-feeling, self-capability based intuition, and risky-fearful abolishment desire to 
thecurrent and future job and career. It potentially influences on personal commitment and creating human capital (Eka Muzalfitri Ridwan, 2017).

Figure 1. Proposition of Personal FIDES Awareness

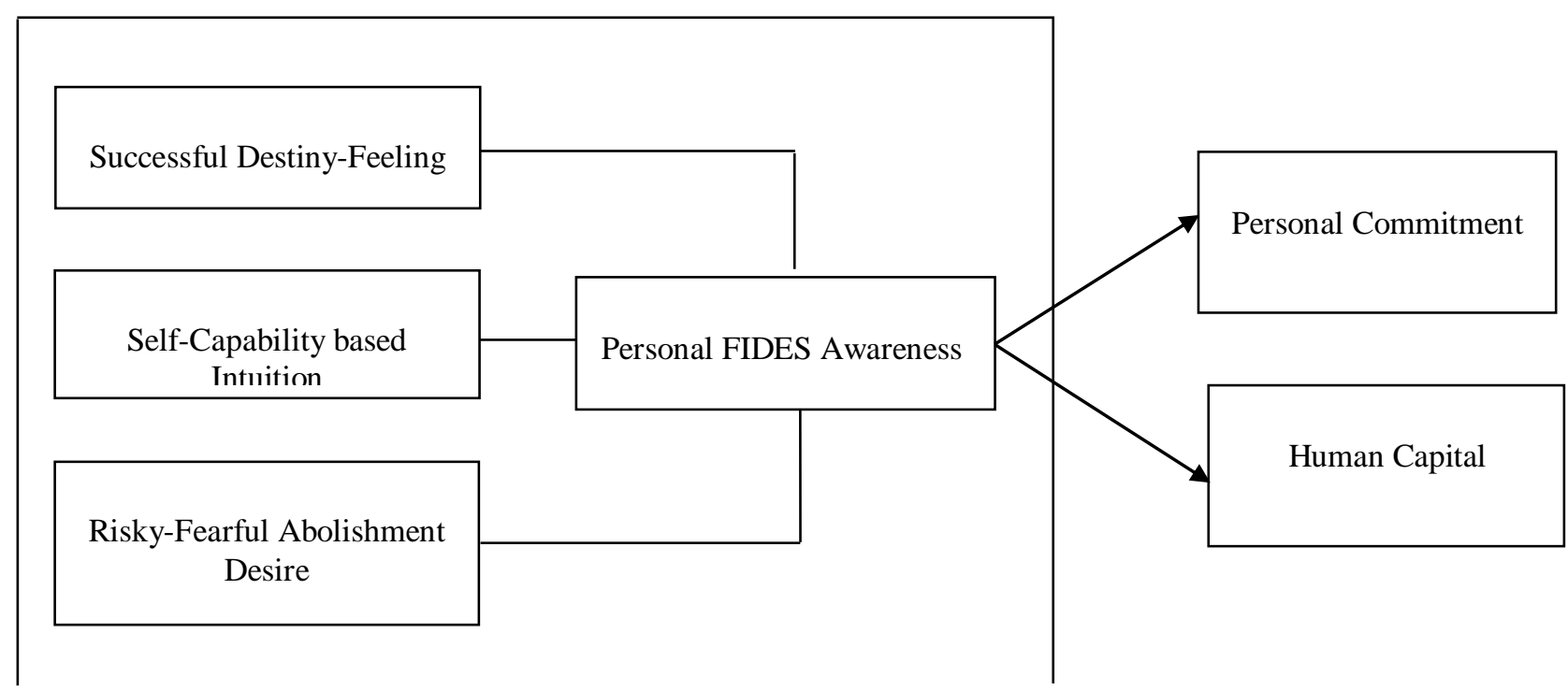

Where FIDES is abbreviation for $F=$ Feeling

$$
\begin{gathered}
I=\text { Intuition } \\
\text { Des }=\text { Desire }
\end{gathered}
$$

The postulate of Future-Anxious Commitment is a personal mindset of exploring, proving, and implementing one's affectionfor its job by concerning personal anxiety of harder opportunity and lost-potential career. It potentially influences on creating human capital (Eka Muzalfitri Ridwan, 2018)

Figure 2.Proposition of Future-Anxious Commitment

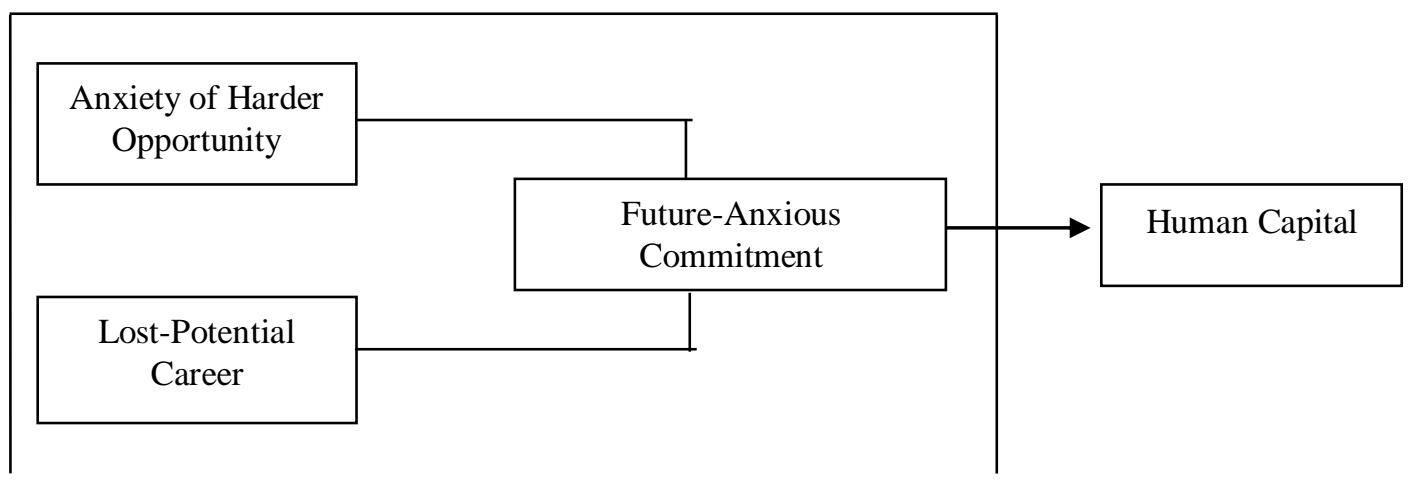




\subsection{Grand-Theoretical Model and Empirical Model}

To expand this research, researcher has deeply though grand-theoretical model as a basis to explain much more the relationship among research constructs and its dimension and indicators, beside that to maintain other novelties in the theory that needed by using new postulate until this research can cover new and strategic solution for the specific problems in South Sumatera Province in the light of different problems and symptoms in different countries even provinces.

The grand-theoretical model in this research can figured like at figure 3 below:

Figure 3. Grand-Theoretical Model

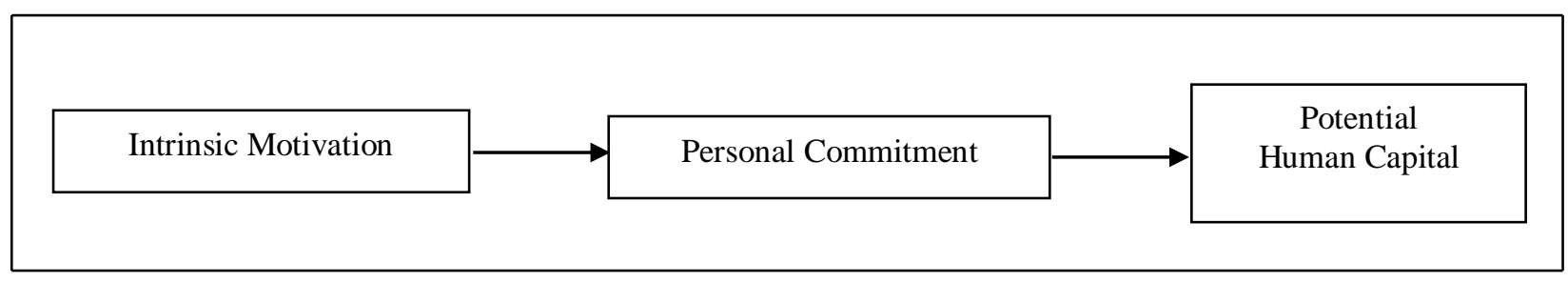

Source: Cordova, D. I., \& Lepper, M. R and John P. Meyer and Natalie J. Allen

That grand-theoretical model is based on some empirical studies that have been published in some international journals which are indexed by SCOPUS. The relationship between intrinsic motivation and personal commitment is duplicated from Cordova, D. I., \& Lepper, M. R. (1996). The relationship between commitment and human capital and performance is duplicated from John P. Meyer and Natalie J. Allen (2001).

The empirical model can be built by using new construct that substituted the previous construct in the grand-theoretical model. In this research, researcher add some construct in the empirical model to enrich this research scientifically and measurably. The empirical model in this research can be figured below:

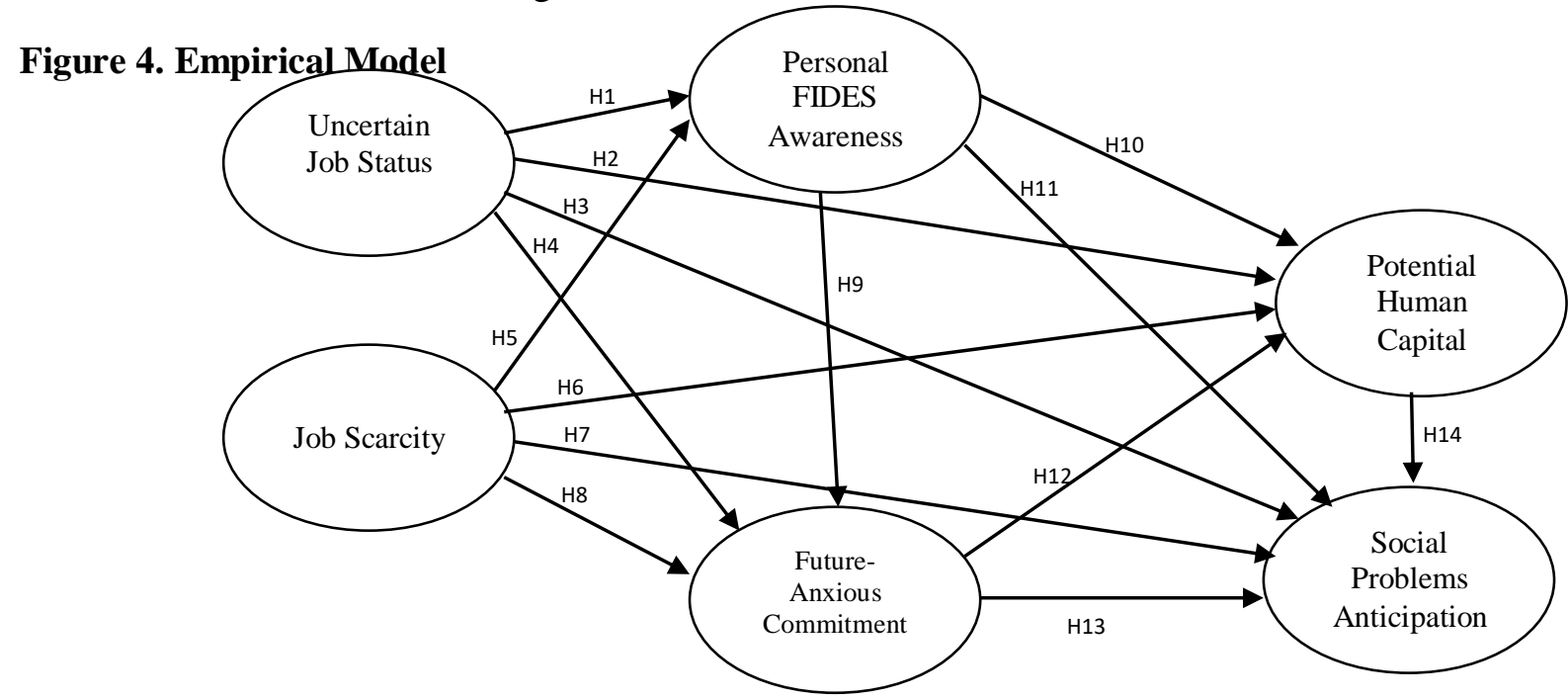

Source: Eka Muzalfitri Ridwan, 2018 


\subsection{Hypothesis}

This research needs to be justified by using statistical theory and special programme. It means the research that needs a justification so some hypothesis are a must. The hypothesis can be explained below:

H1 : Uncertain Job Status has significant influence on Personal FIDES Awareness

H2 : Uncertain Job Status has significant influence on Potential Human Capital

H3 : Uncertain Job Status has significant influence on Social Problems Anticipation

H4 : Uncertain Job Status has significant influence on Future-Anxious Commitment

H5 : Job Scarcity has significant influence on Personal FIDES Awareness

H6 : Job Scarcity has significant influence on Potential Human Capital

H7: Job Scarcity has significant influence on Social Problems Anticipation

H8 : Job Scarcity has significant influence on Future-Anxious Commitment

H9 : Personal FIDES Awareness has significant influence on Future-Anxious Commitment

H10 : Personal FIDES Awareness has significant influence on Potential Human Capital

H11 : Personal FIDES Awareness has significant influence on Social Problems Anticipation

H12 : Future-Anxious Commitment has significant influence on Potential Human Capital

H13 : Future-Anxious Commitment has significant influence on Social Problems Anticipation

H14 : Potential Human Capital has significant influence on Social Problems Anticipation

\section{Research Methodology}

The method of this research can be described by explaining the type of research, population and sample, research construct/variable and its measures, and the source of data.

\subsection{The Type of Research}

This research explain the influence of Future-Anxious Commitment on Potential human Capital and Social Problems anticipation with Personal FIDES Awareness as mediating variable. It means this research includes into the causality research that aims to test the causalities among research variables that determined by using research hypothesis and hoped the result of this can predict and generate some inventionsfrom causal relationship.

\subsection{Population and samples}

Researcher uses survey method to collect the populations and samples, it means researcher himself and some volunteers directly come and approach to the lecturers and teachers as the objects of the samples to spread abroad all the questionnaires until we can get the data valid and reliable.

The populations of this research are all the outsourcing lecturers at state and private universities and all the outsourcing teachers at state and private elementary schools, junior high schools, senior high schools in South Sumatera - Indonesia.

The samples measurement in this research are around 100 samples to 400 samples. According to Hair (1995) to determine the sample in a research, it all depends on the total number of dimensions of the constructs or the variables that determined in the research, with the formula as: if the total number of the dimensions of the constructs are 50 dimensions, so 5 x 50 dimensions are 250 samples or 10 x 50 dimensions are 500 samples. Researcher 
determines that the total numbers of dimensions of the constructs/variables are 42 dimensions. So the formula will be $10 \times 42$ dimensions $=420$ samples.

\subsection{Research Construct/Variable and Its Measures}

To build the model of the research needs two variables, that is exogenous variable and endogenous variable. To show those variables that can be used from empirical model, that is:

Table 1. Exogenous and Endogenous Constructs/Variables and Its Dimensions

\begin{tabular}{|c|c|}
\hline \multicolumn{2}{|c|}{ Exogenous Constructs/Variables and Its Dimensions } \\
\hline Uncertain Job Status: & Job Scarcity \\
\hline $\mathrm{X} 1=\lambda$ Temporary wages $+\mathrm{e} 1$ & $\mathrm{X} 8=\lambda$ Scarce Information of Vacancy $+\mathrm{e} 8$ \\
\hline $\mathrm{X} 2=\lambda$ Uncertain Authority $=\mathrm{e} 2$ & $\mathrm{X} 9=\lambda$ High Requirement for Skills + e9 \\
\hline $\mathrm{X} 3=\lambda$ Uncertain Top Down Communication $+\mathrm{e} 3$ & $\mathrm{X} 10=\lambda$ High Preference for Work $+\mathrm{e} 10$ \\
\hline $\mathrm{X} 4=\lambda$ Uncertain Destiny of Life $+\mathrm{e} 4$ & $\begin{array}{l}\text { X11= } \lambda \text { Being Custom to be Nepotism \& Collusion }+ \\
\text { e11 }\end{array}$ \\
\hline $\mathrm{X} 5=\lambda$ Uncertain Recognition for Independency $+\mathrm{e} 5$ & $\mathrm{X} 12=\lambda$ Less Industrial Growth $+\mathrm{e} 12$ \\
\hline $\mathrm{X} 6=\lambda$ Uncertain Rules and Procedures $+\mathrm{e} 6$ & $\mathrm{X} 13=\lambda$ Less Scholar Entry $+\mathrm{e} 13$ \\
\hline $\mathrm{X7}=\lambda$ Temporary Opportunity, Career \& & $\mathrm{X} 14=\lambda$ Money Minded-based Recruitment + e14 \\
\hline Development + e7 & $\mathrm{X} 15=\lambda$ Population Explosion Effect $+\mathrm{e} 15$ \\
\hline \multicolumn{2}{|c|}{ Endogenous Construct/Variables and ItsDimensions } \\
\hline Personal FIDES Awareness & Future-Anxious Commitment \\
\hline $\mathrm{X} 16=\lambda$ Globalization in Mechanism System + e16 & $\mathrm{X} 25=\lambda$ Beloved Job Under Pressure + e25 \\
\hline $\mathrm{X} 17=\lambda$ Potential Teenager Boom $+\mathrm{e} 17$ & $\mathrm{X} 26=\lambda$ Profession Pride $+\mathrm{e} 26$ \\
\hline $\mathrm{X} 18=\lambda$ Rising Artificial Intelligence $+\mathrm{e} 18$ & $\mathrm{X} 27=\lambda$ Profession Ideal $+\mathrm{e} 27$ \\
\hline $\mathrm{X} 19=\lambda$ Scaring of Lateness in Career $+\mathrm{e} 19$ & $\mathrm{X} 28=\lambda$ Heading for Broader Insight $+\mathrm{e} 28$ \\
\hline $\mathrm{X} 20=\lambda$ New Opportunity and Challenges $+\mathrm{e} 20$ & $\begin{array}{l}\text { X29 }=\lambda \text { Heading for Broader Knowledge } \& \text { Science }+ \\
\text { e29 }\end{array}$ \\
\hline $\mathrm{X} 21=\lambda$ Competition Booms $+\mathrm{e} 21$ & $\mathrm{X} 30=\lambda \mathrm{Joys}$ for Examining Research $+\mathrm{e} 30$ \\
\hline $\mathrm{X} 22=\lambda$ Exploring NewExperiences $+\mathrm{e} 22$ & $\mathrm{X} 31=\lambda \mathrm{J}$ oys for Facing Challenges $+\mathrm{e} 31$ \\
\hline $\mathrm{X} 23=\lambda$ Scaring of Self Aging $+\mathrm{e} 23$ & $\mathrm{X} 32=\lambda \mathrm{Joys}$ for Creative thinking $+\mathrm{e} 32$ \\
\hline $\begin{array}{l}\text { X24 }=\lambda \text { Desire for Protecting Self \& Family Future }+ \\
\text { e24 }\end{array}$ & \\
\hline
\end{tabular}

\section{The Continuity of Table 1}

Potential Human capital

X33 $=\lambda$ High Personal Independency + e33

$\mathrm{X} 34=\lambda$ High Creative $\&$ Innovative Thinking + e34

X35 $=\lambda$ High Integrity \& Skill Development + e35

X36 $=\lambda$ High Self Motivation \& Dedication + e36

X37 $=\lambda$ High Social and Work Partner Cares + e37
Social Problems-Anticipation

X38 $=\lambda$ Reducing Unemployment + e38

$\mathrm{X} 39=\lambda$ Reducing Poverty $+\mathrm{e} 39$

$\mathrm{X} 40=\lambda$ Alleviating Social Gap + e40

$\mathrm{X} 41=\lambda$ Alleviating Crimes $+\mathrm{e} 41$

$\mathrm{X} 42=\lambda$ Rising Life Hope \&Health Rate + e42

From table 1 above, researcher can conclude structural equation of causality model starts from (1) until (4) like figured below:

\section{Structural Equation}

Personal FIDES Awareness $=\beta_{1}$ UncertainJob Status $+\beta_{2}$ Job Scarcity $+\mathrm{Z} 1$

Future-Anxious Commitment $=\beta_{1}$ UncertainJob Status $+\beta_{2}$ Job Scarcity $+\gamma_{1}$ PersonalFIDES Awareness + $\mathrm{Z} 2 \ldots$ 

Potential Human Capital $=\beta_{1}$ UncertainJob Status $+\beta_{2}$ Job Scarcity $+\gamma 1$ PersonalFIDES Awareness + $\gamma 2$ Future-Anxious Commitment $+\mathrm{Z} 3$

Social Problems Anticipation $=\beta_{1}$ UncertainJob Status $+\beta_{2}$ Job Scarcity $+\gamma 1$ Personal FIDES Awareness + $\gamma$ 2Future-Anxious Commitment $+\gamma 3$ Potential Human capital + Z4

This research uses structural equation modeling as a computation because the research model has more than four constructs and its 42 (fourty-two) dimensions (including its indicators), meanwhile researcher uses AMOS programme to compute the result of research model because this research has 408 (four hundreds and eight) samples.

Likert Scale is used in this research with the rating scale starts from 1 until 10, the distance (scale 1-10) is chosen in proportion to give opportunities for respondents (outsourcing lecturers and outsourcing teachers) to fairly and freely choose their opinions toward the statements of the questionnaires prepared anddisseminated. This likert scale with the rating 1-10 includes into ordinal data, so it is wise to be transformed to become interval data by using MSI programme (Method of Successive Interval) in consideration that the ordinal data belongs to the scale of respondents' attitudes that has to be transformed into interval data that has a meaning even though null value is not an absolute value in that data.For the illustration of the data scale can be describedbelow:

The statement of Future-Anxious Commitment:

"You love your job very much as a profession despite of under pressure."

$\begin{array}{llllllllll}1 & 2 & 3 & 4 & 5 & 6 & 7 & 8 & 9 & 10\end{array}$

In research model evaluation, researcher work by Goodness of Fit orientation with the conditions like: normality with standard critical value between $\mathbf{\pm 2 , 5 8}(<2,58$ or $>-2,58)$ with rate of significance $0,01, \chi^{2}$ Chi-Square Statisticin minimum value, RMSEA (The Root Mean Square Error of Approximation) < 0,08, GFI (Goodness of Fit Index) with the scale $\geq$ 0,90, AGFI (Adjusted Goodness of Fit Index) with the scale $\geq 0,90$, CMIN/DF (value of ChiSquare is divided by degree of freedom) with the scale $\leq 2,00$, TLI (Tucker Lewis Index) with the scale $\geq 0,95$, and CFI (Comparative Fit Index) with the scale $\geq 0,95$.

Validity and reliability test are implemented to measure all the items of the indicators in the questionnaires related to the research constructs/variables. Researcher determines that if the result test of the data shows Cronbach Alpha> 0,60 (Nunally, 1967) it means the data of the research is reliable. Meanwhile for validity test an indicator of the constructs can be called valid if the score of the loading factors of the research model is $\geq 0,30$ (rules of thumbs, Imam Ghozali, 2008).

\subsection{The Source of The Data}

The data of this research are collected by directly observing to the respondents in the colleges and schools and giving them the questionnaires and then asking them to fulfill all the questions or statements prepared in it. The total number of data are 420 samples $(10 \times 42$ indicators of research constructs), but were collected just 408 samples, because 6 units of questionnaires were not complete in its answers, 3 units of questionnaires were broken, and the others were not back from the respondents. 
The research result is done by analyzing and deepen many relevant references and empirical journal related to the symptoms and problems of this research.

\section{Discussion}

Research findings and its explanations can be analyzed in this chapter by describing empirical model completed with its loading factors, Goodness of Fit, and the final findings, like the explanations below:

\subsection{Full Empirical Model Test 1}

The result of empirical model test is divided into two steps, it is reasonable because from first test ,exactly the model is not fit enough, it can be described from its Goodness of Fit model, and beside that not all the hypothesis are accepted because the results of the direct and indirect effects generate that its relationships are in negative value and less than 1, like it is described from the figure 5 below:

\section{Figure 5. Full Empirical Model 1}

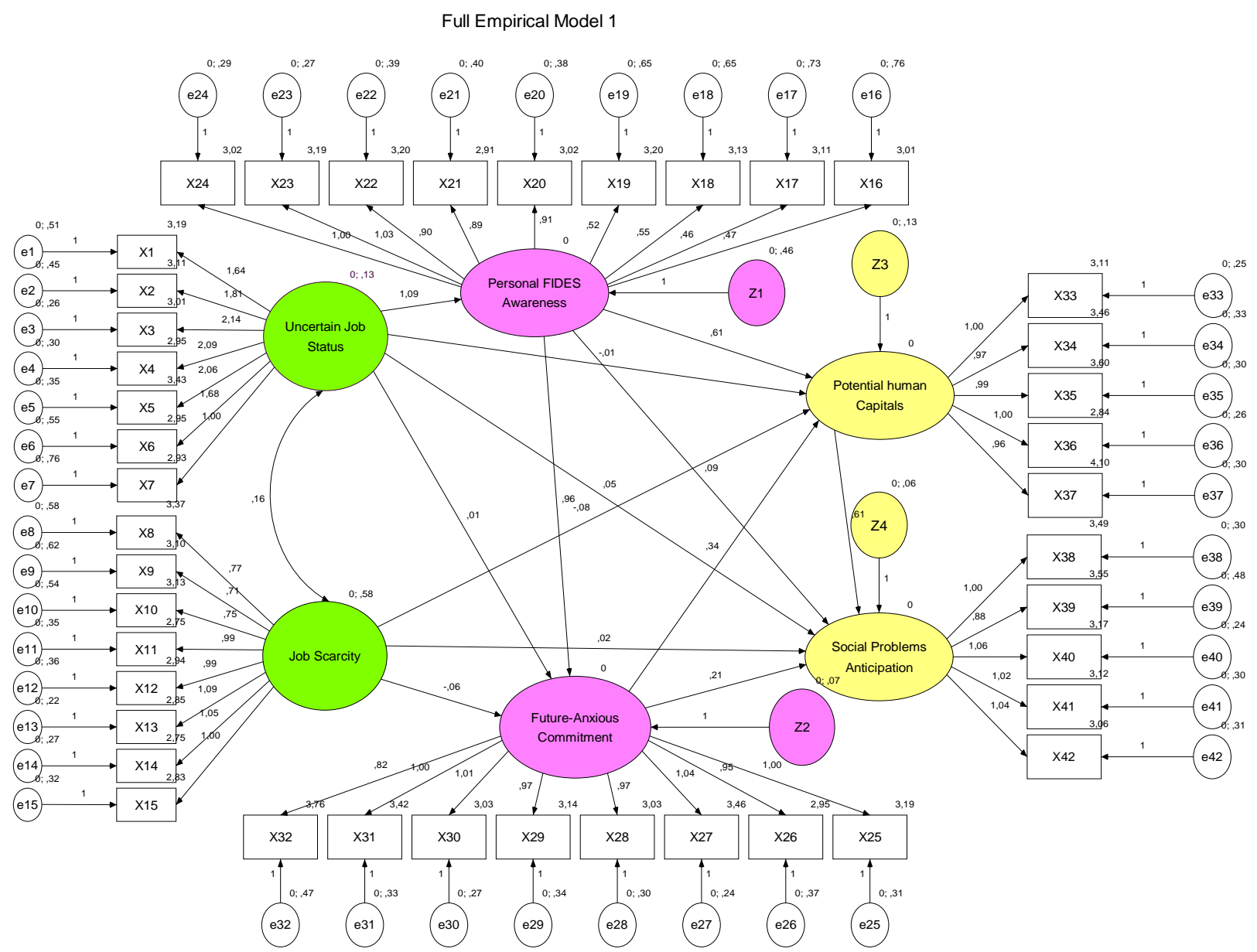

Source: Eka Muzalfitri Ridwan, 2018 
From the figure 5 (full empirical model 1) describes that all the loading factors yield 0,30 even more than 0,30 so there is no dimension or indicators of the research constructs to be loosen but the direct and indirect relationship are in negative value and the result by using Goodness of Fit describes shows that the empirical model 1 is not fit enough because its conditions are not attained, like the table 6 below:

Tabel2. Result of Goodness of Fit Test of Full Empirical Model 1

\begin{tabular}{|l|c|c|c|}
\hline \multicolumn{1}{|c|}{ Goodness of Fit Index } & Cut-Off Value & Model Result & Model Evaluation \\
\hline Chi-Square $(\mathrm{df}=80, \lambda=5 \%)$ & $<101,884$ & 522,65 & Not good \\
\hline Significance Prob & $\geq 0,05$ & 0,000 & Not good \\
\hline RMSEA & $\leq 0,08$ & 0,116 & Not good \\
\hline GFI & $\geq 0,90$ & 0,821 & Not good \\
\hline AGFI & $\geq 0,90$ & 0,804 & Not good \\
\hline CMIN/DF & $\leq 2,00$ & 3,493 & Not good \\
\hline TLI & $\geq 0,95$ & 0,690 & Not good \\
\hline CFI & $\geq 0,95$ & 0,710 & Not good \\
\hline
\end{tabular}

Source: The Data Processed, 2019

\subsection{Full Empirical Model Test 2}

The result of full empirical model test 2 is good enough, it is reasonable because the loading factors are more than standard value $\geq 0,30$, and the result of goodness of Fit for the model is fit enough. The full empirical model 2 is rebuilt and changed in consideration of losing negative value on its direct and indirect relationship among it research constructs/variables, like the figure 6 below:

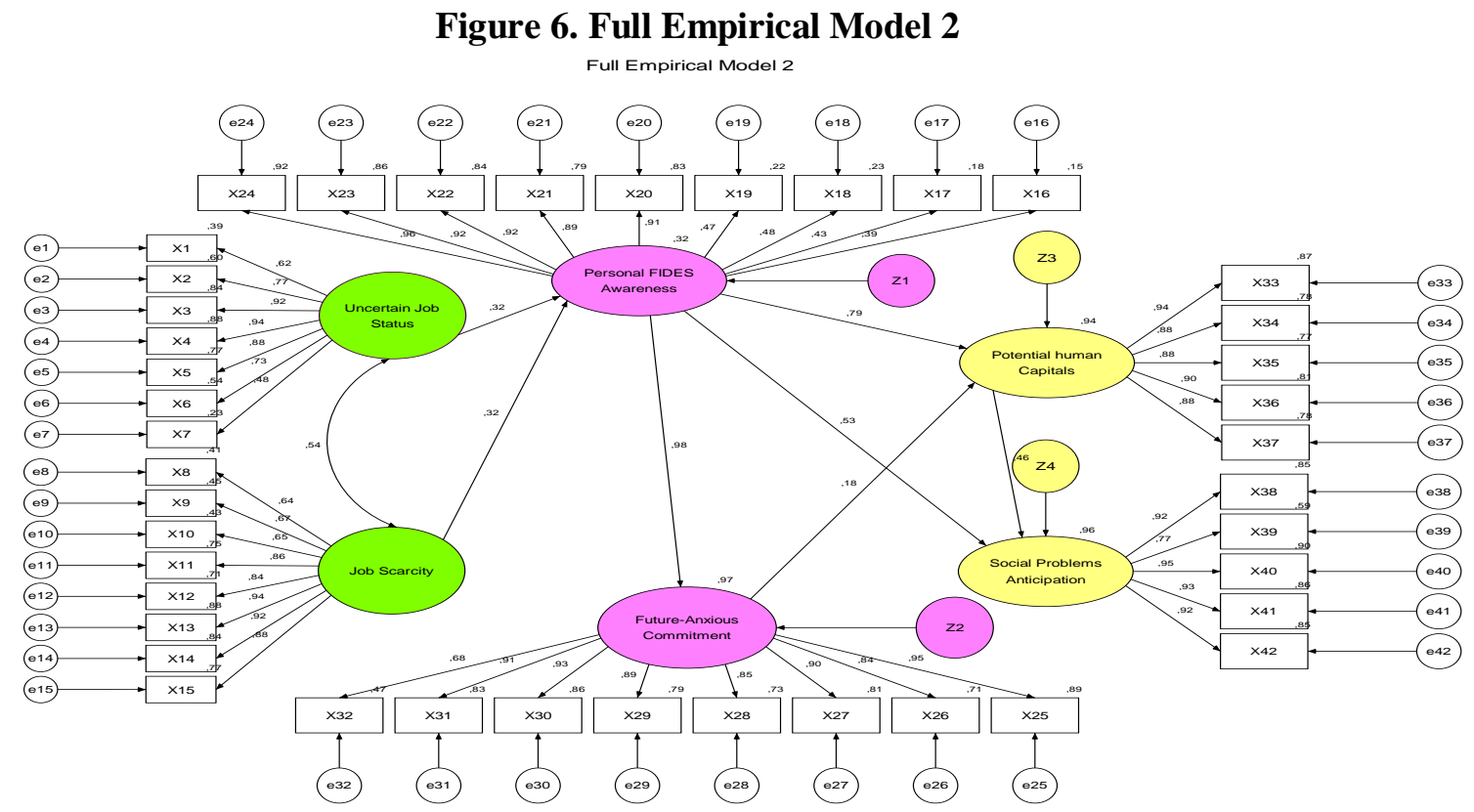

Source: Eka Muzalfitri Ridwan, 2018 
Table 3. Result of Goodness of Fit Test of Full Empirical Model 2

\begin{tabular}{|l|c|c|c|}
\hline \multicolumn{1}{|c|}{ Goodness of Fit Index } & Cut-Off Value & Model Result & Model Evaluation \\
\hline Chi-Square $(\mathrm{df}=81, \lambda=5 \%)$ & $<103,009$ & 101,650 & Good \\
\hline Significance Prob & $\geq 0,05$ & 0,071 & Good \\
\hline RMSEA & $\leq 0,08$ & 0,062 & Good \\
\hline GFI & $\geq 0,90$ & 0,912 & Good \\
\hline AGFI & $\geq 0,90$ & 0,904 & Good \\
\hline CMIN/DF & $\leq 2,00$ & 1,989 & Good \\
\hline TLI & $\geq 0,95$ & 0,964 & Good \\
\hline CFI & $\geq 0,95$ & 0,941 & Good \\
\hline HOELTER & $\geq 100(\mathrm{p}=5 \%)$ & 109 & \\
\hline
\end{tabular}

Source: The Data Processed, 2018

This research uses full empirical model 2, because its model is fit if we check it from Goodness of Fit Test. Beside that we can also check it from assessment of normality by using Maximum Likelihood Estimation Technique, it means the data is accepted if values of critical ratio or c.r (Skewness and Kurtosis) not more than 2,58 $(\leq 2,58)$ or more than $-2,58(\geq-$ 2,58 ), and the full empirical model 2 can fulfill the condition of assessment of normality like figured as table 4.c that the total number of critical ratio for multivariate is 1,857 meant the value is less than $+2,58(\leq+2,58)$. The conclusion is that full empirical model 2 does not have multivariate outliers and the model has normality in multivariate. The table 4shows assessment of normality that can be figured below:

Table 4.Assessment of normality

\begin{tabular}{|c|c|c|c|c|c|c|}
\hline Variable & min & max & skew & c.r. & kurtosis & c.r. \\
\hline X37 & 1,000 & 5,144 &,- 424 & $-2,499$ &,- 744 & $-2,066$ \\
\hline X36 & 1,000 & 4,179 &,- 166 & 1,371 &,- 776 & 2,201 \\
\hline X35 & 1,000 & 4,751 &,- 338 & $-1,786$ &,- 689 & $-1,840$ \\
\hline X20 & 1,000 & 3,988 &,- 493 & $-2,068$ &,- 848 & $-2,496$ \\
\hline X21 & 1,000 & 3,990 &,- 349 & $-1,875$ &,- 923 & $-1,807$ \\
\hline X22 & 1,000 & 4,227 &,- 435 & $-1,590$ &,- 797 & $-1,286$ \\
\hline X5 & 1,000 & 4,533 &,- 367 & $-2,027$ &,- 781 & $-2,222$ \\
\hline X6 & 1,000 & 4,122 &,- 283 & $-2,337$ &,- 897 & $-1,697$ \\
\hline X7 & 1,000 & 3,934 &,- 424 & $-1,493$ &,- 926 & $-1,820$ \\
\hline X8 & 1,000 & 4,483 &,- 377 & 1,112 &,- 715 & 1,950 \\
\hline X9 & 1,000 & 4,244 &,- 310 & $-2,560$ &,- 834 & $-1,441$ \\
\hline X10 & 1,000 & 4,150 &,- 401 & $-1,303$ &,- 859 & $-1,543$ \\
\hline X11 & 1,000 & 3,942 &,- 233 & 1,925 &,- 982 & 2,051 \\
\hline X12 & 1,000 & 4,147 &,- 257 & 2,117 &,- 853 & 2,517 \\
\hline X13 & 1,000 & 3,949 &,- 322 & 1,657 &,- 964 & 1,973 \\
\hline X14 & 1,000 & 3,865 &,- 285 & $-2,354$ & $-1,018$ & $-2,198$ \\
\hline X15 & 1,000 & 3,839 &,- 400 & 2,299 & $-1,003$ & 2,135 \\
\hline Multivariate & & & & & 33,410 & $\mathbf{1 , 8 5 7}$ \\
\hline
\end{tabular}

Source: Data Processed, 2018 


\subsection{Data Representations}

Figure of full empirical model 2gives description data representation like:usingMahalanobis distance to know there will be or not outlier in the model like which is described on Table 5:

Table 5. Mahalanobis Distance

\begin{tabular}{|c|c|c|c|}
\hline Observation number & Mahalanobis d-squared & $\mathrm{p} 1$ & $\mathrm{p} 2$ \\
\hline 36 & $\mathbf{9 0 , 7 7 3}$ &, 000 &, 008 \\
\hline 406 & 86,950 &, 000 &, 000 \\
\hline 127 & 86,624 &, 000 &, 000 \\
\hline 84 & 82,086 &, 000 &, 000 \\
\hline 153 & 81,692 &, 000 &, 000 \\
\hline 77 & 75,718 &, 001 &, 000 \\
\hline 90 & 73,196 &, 002 &, 000 \\
\hline 131 & 73,175 &, 002 &, 000 \\
\hline 123 & 72,788 &, 002 &, 000 \\
\hline 404 & 72,579 &, 002 &, 000 \\
\hline 89 & 72,457 &, 002 &, 000 \\
\hline 128 & 71,695 &, 003 &, 000 \\
\hline 83 & 71,535 &, 003 &, 000 \\
\hline 188 & 71,237 &, 003 &, 000 \\
\hline
\end{tabular}

Source: Data Processed, 2018

The table 5 shows that all values of Mahalanobis d-squared for the most maximum value is only 90,773, it is meant if it is compared with the value of Chi-Square of full empirical model 2 which its value is 101,650 (see table 4.b on page 12) that value of mahalabis d-square is less than value of Chi-Square $(90,773<101,650)$ and it can be concluded that full empirical model 2 has no multivariate outlier in its data.

\subsection{Validity and Reliability Test}

Researcher thinks that analyzing validity and reliability test are important enough to convince us is all data proper to be used in a research. Validity test means a kind of test to make sure that all dimensions and indicators used in the research can exactly reflect the constructs or the variables of the research model determined (Ferdinand, 2017). One of the way of knowing the value of validity rate in the research is by using loading factors of the research model in AMOS programme. This research uses AMOS programme as a supporting aid to assist researcher to finish this research and from the result of AMOS programme in its full empirical model 2 shows that all the loading factors of the research model have the grade rate minimum 0,43 and can be concluded that data is valid because the grade is more than 0,30 (Imam Ghozali, 2008). Beside that, researcher uses SPSS programme to measure the validity test by using value of $\quad t_{\text {table }}$ (with $\alpha=5 \%$ - two tailed, $\mathrm{df}=81$ ) is 1,6639 and $\mathrm{r}_{\text {table }}$ (with $\alpha=5 \%$ - two tailed, $\mathrm{df}=81$ ) is 0,1818 . The results of SPSS programme show thatfor the construct of uncertain job status is 0,637 , job scarcity is 0,783 , personal FIDES Awareness is 0,863 , future-anxious commitment is 0,876 , potential human-capital is 0,818 , and social problems-anticipation is 0,680 (see table 6). it can be concluded that all the values of the constructs are more than the value of $r_{\text {table }}$ and all the constructs are valid. 
Table6. Item-Total Statistics

\begin{tabular}{|l|r|r|r|r|r|}
\hline & $\begin{array}{c}\text { Scale Mean if } \\
\text { Item Deleted }\end{array}$ & $\begin{array}{c}\text { Scale Variance if } \\
\text { Item Deleted }\end{array}$ & $\begin{array}{c}\text { Squared } \\
\text { Corrected Item- } \\
\text { Total Correlation }\end{array}$ & $\begin{array}{c}\text { Cronbach's } \\
\text { Alpha if Item } \\
\text { Correlation }\end{array}$ & $\begin{array}{c}\text { Celeted } \\
\text { Deled }\end{array}$ \\
\hline Job_Status & 37.71 & 161.486 & .637 & .594 & .924 \\
Job_scarcity & 38.19 & 144.891 & .783 & .731 & .906 \\
Personal_FIDES_Awareness & 38.33 & 137.760 & .863 & .799 & .892 \\
Future_Anxious_Commitme & 38.35 & 137.506 & .876 & .892 \\
nt & & & .818 & .739 & .502 \\
Potential_human_Capital & 38.32 & 145.663 & .680 & .901 \\
Social_Problems_Anticipatio & 38.61 & 148.287 & .921 \\
n & & & & .502 \\
\hline
\end{tabular}

Source: Data Processed, 2017

The other way, validity test can be computed by using correlation analysis of bivariate shows that all the constructs of this research have values more than 0,5 that means all constructs are valid because they have significant relations (see table 7 below)

Table 7. Correlations

\begin{tabular}{|c|c|c|c|c|c|c|c|}
\hline & & $\begin{array}{c}\text { Job_Statu } \\
\text { s }\end{array}$ & $\begin{array}{c}\text { Job_scarcit } \\
y\end{array}$ & $\begin{array}{c}\text { Personal_FIDES } \\
\text { _Awareness }\end{array}$ & $\begin{array}{c}\text { Future_Anxious } \\
\text { _Commitment }\end{array}$ & $\begin{array}{c}\text { Potential_human } \\
\text { Capital }\end{array}$ & $\begin{array}{c}\text { Social_Problems } \\
\text { _Anticipation }\end{array}$ \\
\hline \multirow[t]{3}{*}{ Job_Status } & $\begin{array}{l}\text { Pearson } \\
\text { Correlation }\end{array}$ & 1 & $.764^{* * *}$ & $.540^{* *}$ & $.570^{* * *}$ & $.496 *$ & $.424 \%$ \\
\hline & Sig. (2-tailed) & & .000 & .000 & .000 & .000 & .000 \\
\hline & $\mathrm{N}$ & 408 & 408 & 408 & 408 & 408 & 408 \\
\hline \multirow[t]{3}{*}{ Job_scarcity } & $\begin{array}{l}\text { Pearson } \\
\text { Correlation }\end{array}$ & $.764^{* * *}$ & 1 & $.732^{* *}$ & $.710^{* *}$ & $.637^{* * *}$ & $.520^{* *}$ \\
\hline & Sig. (2-tailed) & .000 & & .000 & .000 & .000 & .000 \\
\hline & $\mathrm{N}$ & 408 & 408 & 408 & 408 & 408 & 408 \\
\hline \multirow{3}{*}{$\begin{array}{l}\text { Personal_FI } \\
\text { DES_Aware } \\
\text { ness }\end{array}$} & $\begin{array}{l}\text { Pearson } \\
\text { Correlation }\end{array}$ & $.540^{* * *}$ & $.732^{* * *}$ & 1 & $.864^{* *}$ & $.797^{* * *}$ & $.670^{* *}$ \\
\hline & Sig. (2-tailed) & .000 & .000 & & .000 & .000 & .000 \\
\hline & $\mathrm{N}$ & 408 & 408 & 408 & 408 & 408 & 408 \\
\hline \multirow{3}{*}{$\begin{array}{l}\text { Future_Anxi } \\
\text { ous_Commit } \\
\text { ment }\end{array}$} & $\begin{array}{l}\text { Pearson } \\
\text { Correlation }\end{array}$ & $.570^{* * *}$ & $.710^{* * *}$ & $.864^{* *}$ & 1 & $.842^{* * *}$ & .666 ** \\
\hline & Sig. (2-tailed) & .000 & .000 & .000 & & .000 & .000 \\
\hline & $\mathrm{N}$ & 408 & 408 & 408 & 408 & 408 & 408 \\
\hline \multirow[t]{3}{*}{$\begin{array}{l}\text { Potential_hu } \\
\text { man_Capital }\end{array}$} & $\begin{array}{l}\text { Pearson } \\
\text { Correlation }\end{array}$ & $.496 * *$ & $.637^{* * *}$ & $.797^{* *}$ & $.842^{* * *}$ & 1 & $.664^{* *}$ \\
\hline & Sig. (2-tailed) & .000 & .000 & .000 & .000 & & .000 \\
\hline & $\mathrm{N}$ & 408 & 408 & 408 & 408 & 408 & 408 \\
\hline \multirow{2}{*}{$\begin{array}{l}\text { Social_Probl } \\
\text { ems_Anticip } \\
\text { ation }\end{array}$} & $\begin{array}{l}\text { Pearson } \\
\text { Correlation }\end{array}$ & $.424^{* *}$ & $.520^{* *}$ & $.670^{* *}$ & $.666^{* * *}$ & $.664^{* * *}$ & \\
\hline & Sig. (2-tailed) & .000 & .000 & .000 & .000 & .000 & \\
\hline
\end{tabular}




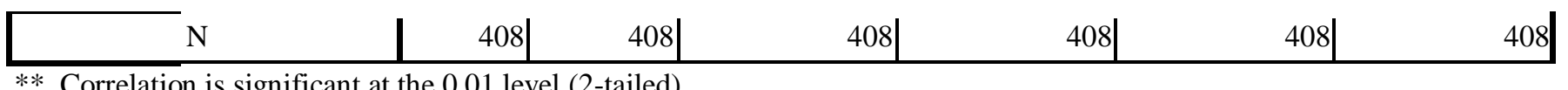

Reliability test means a kind of a test that all the data (the questionnaires) have to be fulfilled/answered by the right persons which are members of the samples that determined in the research (Ferdinand, 2017). Researcher can use Cronbach's Alpha (with the grade rate $\geq$ $0,60)$ as an orientation to decide the data in the research can be reliable or not reliable (Nunnaly, J, 1967)

The result of AMOS programme shows that Cronbach's Alpha based on standardized item is 0,922 , it is meant that all data in this research is reliable because 0,922 is bigger than 0,60 as a base grade (see table 8 )

Table 8. Reliability Statistics

\begin{tabular}{|r|r|r|}
\hline Cronbach's Alpha & $\begin{array}{c}\text { Cronbach's Alpha Based on } \\
\text { Standardized Items }\end{array}$ & N of Items \\
\hline .921 & .921 & 6 \\
\hline
\end{tabular}

\subsection{Research Findings}

From full empirical model 2 yields there are positive relationships among uncertain job status with personal-FIDES Awareness, job scarcity with personal-FIDES Awareness, personal-FIDES Awareness with future-anxious commitment, personal-FIDES Awareness with potential human capitals, future-anxious commitment with potential human capitals, potential human capitals with social problems anticipation, and personal-FIDES Awareness with social problems anticipation. In other hand, there is a significant influence between personal-FIDES Awareness on future-anxious commitment with $98 \%$ grade, and personalFIDES Awareness on potential human capitals 79\% grade, and personal-FIDES Awareness on social problems anticipation with $53 \%$ grade.

The outsourcing lecturers and teachers felt that if they left their job or profession, they could be one of the unemployment and it was very hard to find other jobs not only in formal sectors but also in informal sectors in South Sumatera Province. This situation needs bright mind and thought of the outsourcing lecturers and teachersto hold out their position as the outsourcing ones at colleges and schools until they can catch their personal awareness (called personal FIDES awareness) that loving and concentrating on their job/profession is more important than getting big salaries, and be convinced that psychological condition will generate personal commitment to their job/profession (called future-anxious commitment).

\section{Conclusion}

Research findings and its explanations can be analyzed in this chapter by describing empirical model completed with its loading factors. Humans especially the experienced and the skilled ones are the most important thing of the resource in an organization. They are human resources that needed in many sectors and departments not only in creating innovation and discoveries but also generating a problem solving in purpose for developing governance of an organization. It is a ridiculous attempt, a leader or owner of an organization just think 
of gaining source of material, source of infrastructure, source of basis land, source of funds, and source of technology if there is no human resource or no care about their surrounding employees. Outsourcing lectures and teachers are one of potential human resources that must be protected, cared of, held, respected, and recognized by the owner to increase and stimulate their bright ideas until there will be some innovative and futuristic breakthroughs for developing their college and school until ac compete with other excellent college and school.

From this research, researcher have found many findings that many unsatisfiedoutsourcing lecturers and teachers have been moving and working to abroad to do their profession to abroad, even many of them have changed their citizenship to become abroad citizenship because of their unsatisfied treatment in south sumatera colleges and schools. Meanwhile, in every next one year, South Sumatera has many candidates of new college students and studentsthat want to apply for their position in the college or school that he/she wishes. It is meant that condition is very dangerous because how can the institution (college and school) serve all the educational societies if it is lack of lecturers and teachers, meanwhile these current and next years the government had been decided to do moratorium recruitment of public servants in many sectors since Susilo Bambang Yudhoyono was as a president of Republic of Indonesia, meanwhile private colleges and private schools in South Sumatera are crisis in financial position to hold a new recruitment and teaching and learning programme. Besides that many lecturers and teachers of state college and state school and their status are as public servants are getting pension in the early time, many of them are dead because of age, many of them are getting ill and old and this condition is getting worse serious when in the fact that many outsourcing lecturers and teachers had been getting an exodus to abroad to be a full-time workers. This becomes social problems and add macro economic problems for government of South Sumatera, like adding crimes, adding unemployments in many sectors, worse service and performance in educational sector because this sector can not be well served, and adding poverty problems.

Government in South Sumatera Province and the central government in Jakarta must take care of this condition and it is an urgent must by caring of outsourcing lecturers and teachers in South Sumatera and changing their prosperity by rearranging the salary awardingsystem until their prosperity can be better as far as they wish. Beside that, government and the owner of institution must give similar status and personal rights to have authority, position, career and salary which is suitable with what they have attempted to their job. Having similar opportunity is a must in this condition, because this can motivate and generate higher self-confidence among outsourcing lecturers and teachers.

From this research, researcher has found that personal awareness has saved that condition and this awareness called personal FIDES awareness. It means outsourcing lecturers and teachers won't leave their institution because they are still loyal with institution in concerning with the existence of changing man work to mechanic systems, booming in potential teenager that can compete and threat the older lecturers and teachers, rising artificial intelligence that can substitute a man's profession with a robotic and computerized system in every jobs, getting late in catching career at college or school that has been loved, getting challenging and shock opportunities in educational institution, scaring of many competitors aroused, getting new experience with students, scaring of getting old and getting lost in their jobs, and strong desire for protecting future destiny of itself and family. This personal FIDES awareness strongly influence personal commitment at work called future-anxious 
commitment that consists of still working although under pressure, having profession pride of being lecturer or teacher, strong desire to get broader insight, having knowledge and science, joys for examining research, joys for facing challenges, and joys for creative thinking. By implementing and feeling personal FIDES awareness until strongly feeling future-anxious commitment in every lecturer and teacher hoped can solve and anticipate social problems for government and increase potential human capital for societies and profit and nonprofit institution (especially colleges and schools) In South Sumatera.

\section{References}

Allen, N. J., \& Meyer, J. P. "The measurement and antecedents of affective, continuance and normative commitment." Journal of Occupational Psychology, 63, 1-18. (1990)

Augusty Tae Ferdinand, "Structural Equation modeling.", (Third edition), Diponegoro university Publisher, 2017.Belinda Renee Barnett, Lisa Bradley, "The impact of organisational support for career development on career satisfaction,", Emerald Group Publishing Limited 1362-0436, 2007

Connell, J. P. \& Ryan, R. M. "A Developmental Theory of Motivation in the classroom Teacher Education Quality,” 11, pp. 64-77. 1984

Connell, J. P. \& Ryan, R. M. " A Developmental Theory of Motivation in the classroom." Teacher Education Quality, 11, pp. 64-77, 1984

Cordova, D. I., \& Lepper, M. R. (1996). "Intrinsic motivation and the process of learning: beneficial effects of contextualization, personalization, and choice."Journal of Educational Psychology, 88, 715-730. http://dx.doi.org/10.1037/0022$\underline{0663.88 .4 .715}, 1996$

David G. Coolings and Geoffrey Wood, "Human Resource Management, A Critical Approach." Routledge 2 Park Square, Milton Park, Abingdon, Oxon OX14 4RN, 2015.

Department of Labor Women's Bureau, "Employment status of women and men in 2006.”Retrieved from http://www.dol.gov/wb/factsheets/QfESWM06.htm, 2005

Durkin, M., \& Bennett, H. , "Employee commitment in retail banking: Identifying and exploring hidden dangers." International Journal of Banking, 17(3), 124137. (1999)

Feirong Yuan and Richard W. Woodman, "Innovative Behavior in The Workplace: The Roleof Performance and Image Outcome Expectations." Academy of Management Journal, 2010, Vol. 53, No. 2, 323-342., 2010

Filak, V. F. \& Sheldon, K. M. "Student Psychological Need Satisfaction and College Teacher-Course Evaluations." Educational Psychology, Vol. 23, No. 3, pp. 235247. (2003)

Gary Jon Springer, "A Study of Job Motivation, Satisfaction, and Performance among Bank Employees," Journal of Global Business Issues, 2015

Geert Hofstede, "Motivation, Leadership, and Organization: Do American Theories Apply Abroad?", Organizational Dynamic, Summer 1980.

Hair, J.F Anderson, R.E., Tatham, R.L. \& Black, W.C, "Multivariate Data Analysis (Fourth Edition), New Jersey, Prentice Hall, (1995) 
Horwitz, M. F., Heng, T.C., \& Quazi, A.H. "Finders, Keepers? Attracting, motivating and retaining knowledge workers." Human Resource Management Joumal, Vbl 13 No 4, 2003, Pages 23-44, 2003

Imam Ghozali (2008), "Strucctural Equation Modeling, Concept and Application by Using AMOS 16,0 “, Diponegoro University Publisher, 2008.

Joan Marques, "Turning Inward to Connect Outward: Interbeing as motivational Path in today's Workplace", personhood press, 2014

John P. Meyer and Natalie J. Allen, "A Three- Component Conceptualization of Organizational Commitment." Human Resource Management Review, 2001.

John P. Meyer, David J. Stanley, Lynne Herscovitch, and Laryssa Topolnytsky, "Affective, Continuance, and Normative Commitment to the Organization: A Meta-analysis of Antecedents, Correlates, and Consequences." Journal of Vocational Behavior 61, 20-52 (2002)

Luthans, F. “ Organizational Behavior.” 8th ed Boston: Irwin McGraw-Hill, 1998

Meyer, J. P., \& Allen, N. J., "A three-component conceptualization of organizational commitment." Human Resource Management Review, 1, 61-98. 1991

Morrow, P. C., \& Wirth, R. E. "Work commitment among salaried professionals." Journal of Vocational Behavior, 34, 40-56., 1989

Nunnaly, J , "Psychometric Method," New York. Mc. Graw Hill1967.

Nwachukwu Prince Ololube , "Teachers Job Satisfaction and Motivation for School Effect iveness: An Assessment," University of Fin Land, 2016

Ray, J. J. "The Comparative Validity of Likert, Projective and Forced Choice Indices of Achievement Motivation.” Journal of Social Psychology, 111, 6372, 1980

Roxanne Helm-Stevens and Orlando Griego, "A Path Analysis Modelof Intrinsicand Extrinsic Academic Motivation Engagementin Service Learning." Review of Business Research, Volume 9, Number 1, 2009

Scermerhorn, Hunt, and Osborn "Organizational Behavior.", John and Wiley, Inc, 2010 